\title{
Lagrangian study of microbial plankton respiration in the subtropical North Atlantic Ocean: bacterial contribution and short-term temporal variability
}

\author{
Eva Teiraa ${ }^{1, *}$, Sandra Martínez-García ${ }^{1}$, Emilio Fernández ${ }^{1}$, Alejandra Calvo-Díaz ${ }^{2}$, \\ Xosé Anxelu G. Morán ${ }^{3}$ \\ ${ }^{1}$ Departamento Ecoloxía e Bioloxía Animal, Universidade de Vigo, Campus Lagoas-Marcosende 36310 Vigo, Spain \\ ${ }^{2}$ Department of Biological Oceanography, Royal Netherlands Institute for Sea Research (NIOZ), PO Box 59, \\ 1790 AB Den Burg, The Netherlands \\ ${ }^{3}$ Instituto Español de Oceanografía, Centro Oceanográfico de Xixón, Camin de l'Arbeyal s/n, 33212 Xixón, Spain
}

\begin{abstract}
In oligotrophic regions, in situ diel variability of many biological variables has been shown to be often larger than the variability observed over scales of days. However, the short-term temporal variability (scale of hours to days) of microbial plankton respiration has been poorly assessed in oligotrophic waters, due to methodological limitations of the standard oxygen consumption methods (e.g. incubation time $\geq 24 \mathrm{~h}$ ). In order to avoid such constraints, we estimated bacterial and microbial plankton respiration from size-fractionated $(<0.8 \mu \mathrm{m}$ and total) in vivo electron transport system (ETS) activity measurements (incubation time 3 to $5.5 \mathrm{~h}$ ). Temporal variability in both bacterial and total microbial plankton respiration was assessed during 2 Lagrangian studies lasting $8 \mathrm{~d}$ and conducted at the center and the eastern margin of the North Atlantic Subtropical Gyre in autumn 2006. In these studies, size-fractionated in vivo ETS activity was measured in the same parcel of water on 12 occasions at different times of the day. The contribution of bacteria to total microbial community respiration averaged $29 \pm 20$ (SD) \% and was significantly higher in the upper mixed layer than at the base of the euphotic zone. Euphotic depth-integrated microbial community respiration showed high inter- and intra-day variability and was significantly higher in samples collected at night than during the day, despite constant biomass of bacteria, Prochlorococcus, eukaryotic picophytoplankton and total phytoplankton throughout both Lagrangian studies. Our results indicate that microbial community respiration estimates could be biased if short-term variability is not considered.
\end{abstract}

KEY WORDS: Microbial plankton respiration - Bacterial respiration - ETS activity - Temporal variability · Atlantic Ocean

\section{INTRODUCTION}

The subtropical gyres are vast oceanic oligotrophic regions representing about $60 \%$ of the global surface ocean. A rapid expansion of these areas, particularly in the northern hemisphere, has been observed over the last decade, associated with sea surface warming (Polovina et al. 2008). The Eastern North Atlantic Subtropical Gyre is characterized by strong thermal stratification and nutrient depletion in the upper mixed layer for most of the year, which translates into very low lev- els of chlorophyll a $(\mathrm{chl}$ a) and primary production (Teira et al. 2006, Marañón et al. 2007). Phytoplankton biomass, dominated by $<2 \mu \mathrm{m}$ cells, is regulated by high protistan grazing rates (Quevedo \& Anadón 2001). In this region, microbial community respiration rates, estimated from in vitro $\mathrm{O}_{2}$-consumption experiments, consistently exceed the respiration rates derived from the sum of the respiration rates of each microbial group (derived from their biomass and metabolic rates; Marañón et al. 2007, Morán et al. 2007). It has been speculated that long $(24 \mathrm{~h})$ dark bottle incubations 
might cause such discrepancies, increasing bacterial abundance and activity by a factor of 2 to 4 (Pomeroy et al. 1994, Sherr et al. 1999, Gattuso et al. 2002). Changes in bacterial structure and activity may be much more important in pre-filtered samples $(<0.8 \mu \mathrm{m})$ commonly used to assess the bacterial contribution to total microbial community respiration (Malone et al. 1991, Pomeroy et al. 1994, Massana et al. 2001).

Studies conducted in oligotrophic regions show that in situ diel variability of chemical and biological variables (such as chl a fluorescence, particulate organic carbon concentration, cyanobacterial abundance, bacterial abundance and activity) is often larger than the variability observed over scales of days (Vaulot \& Marie 1999, Kuipers et al. 2000, Ghiglione et al. 2007, Claustre et al. 2008), although the magnitude of these diel changes $(<30 \%)$ is not comparable with the aforementioned changes observed in dark bottle incubations. In the oligotrophic ocean surface layer, light intensity and spectra have been found to have pronounced detrimental effects on prokaryotes, which may slow down growth and retard DNA synthesis and cell division (Kaiser \& Herndl 1997, Sommaruga et al. 1999, Van Wambeke et al. 2008). According to Kuipers et al. (2000), bacteria seem to be out-competed by phytoplankton for inorganic nutrients during the day in the euphotic layer of the North Atlantic Subtropical Gyre. Light-dark cycles in viral infection of bacterioplankton could also partially explain diel variability (Bettarel et al. 2002). Vertical migration of zooplankton to the euphotic zone during the night may increase the availability of dissolved organic matter through 'sloppy feeding' and the formation of fecal pellets (Ghiglione et al. 2007). All these processes are missed in the $24 \mathrm{~h}$ dark bottle incubations used for microbial respiration estimates.

Only a few studies of short-term temporal variability (scale of hours to days) in microbial plankton respiration have been conducted in productive coastal zones (Sampou \& Kemp 1994, Pringault et al. 2009). High detection limits of the Winkler method and oxygen microsensors make such studies difficult in oligotrophic regions due to the unavoidable, long incubation times $(>24 \mathrm{~h})$. In order to avoid such long incubations times, we modified the electron transport system (ETS) enzymatic assay in a way that plankton samples are incubated with 2-para(iodo-phenyl)3(nitrophenyl)-5(phenyl)tetrazolium chloride (INT) over relatively short time periods ( 3 to $5.5 \mathrm{~h}$ in oligotrophic waters). The amount of reduced INT salt (INTFormazan, INT-F), which is proportional to the amount of oxygen consumption, is subsequently quantified spectrophotometrically (see details in Martínez-García et al. 2009). In addition, this technique allows post-incubation fractionation into differ- ent size classes, thus avoiding the disruption of the microbial community.

Conceptually, the best approach for temporal variability studies is to follow the same parcel of water over time (Lagrangian studies), which has the advantage that the same planktonic populations are sampled and that confinement artifacts are largely avoided (Fuhrman et al. 1985). In order to assess both inter-day and intra-day temporal variability in both bacterial and total microbial plankton respiration, 2 Lagrangian studies lasting $8 \mathrm{~d}$ were conducted at the center and the eastern margin of the North Atlantic Subtropical Gyre from October to November 2006. Size-fractionated $(<0.8 \mu \mathrm{m}$ or $>0.8 \mu \mathrm{m})$ in vivo ETS activity was measured on 12 occasions at different times of the day during each study, including 4 intra-day intensive samplings (4 incubations per day).

\section{MATERIALS AND METHODS}

Sampling strategy. The CARPOS cruise took place on board the BIO 'Hespérides' from 24 October to 21 November 2006 in the North Atlantic Subtropical Gyre. Two Lagrangian studies were performed at the centre $\left(36^{\circ} \mathrm{W}, 26^{\circ} \mathrm{N}\right.$; LAG-I) and in the eastern margin $\left(26^{\circ} \mathrm{W}, 25^{\circ} \mathrm{N}\right.$; LAG-II) of the gyre (Fig. 1). A drifting buoy was used to track the water mass. The drifter release location in each study was selected according to the dynamic field to avoid the departure of the buoy from the mesoscale study area. The drifters did not significantly deviate from their expected trajectory as indicated by the small variations in the temperature-

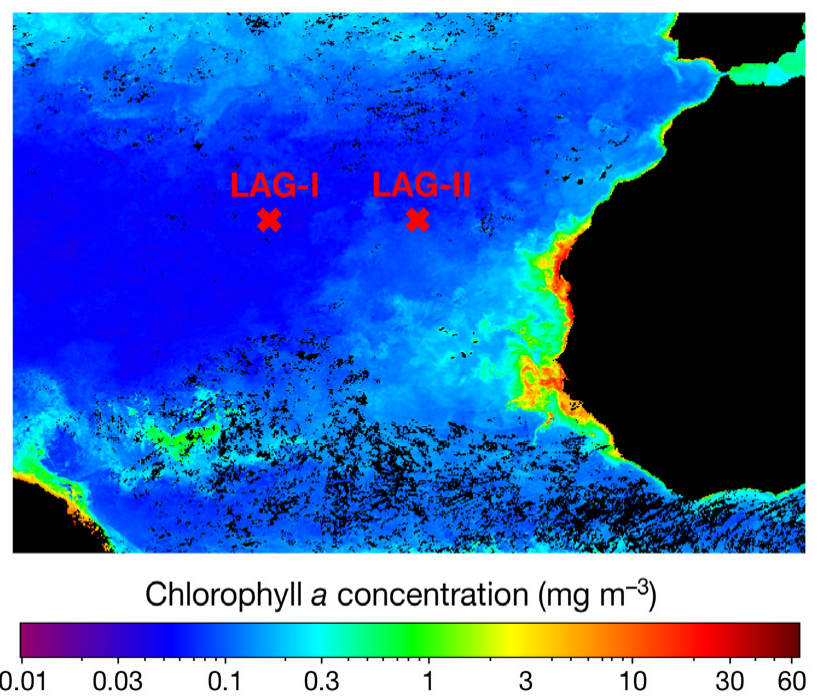

Fig. 1. Locations of the 2 Lagrangian experiments during CARPOS cruise superimposed over a SeaWIFS chlorophyll a monthly composite image (November 2006) 
salinity diagrams (Fig. 2). In both Lagrangian studies, the drifter was briefly recovered after 96 or $144 \mathrm{~h}$ for maintenance and was redeployed 1 to $2 \mathrm{~km}$ from the recovering point 3 to $7 \mathrm{~h}$ later. Each experiment lasted approx. 192 h. During LAG-I, dawn was at 07:30/ 06:30h (local time changed from 28 to 29 October), and dusk was at 18:50/17:50 h. During LAG-II, dawn was at 06:00 $\mathrm{h}$ and dusk was at 17:00 h.

The upper water column (0 to $200 \mathrm{~m}$ ) was sampled using a rosette equipped with twenty-four 121 Niskin bottles and a CTD probe at 24 (Lag-II) to 25 (Lag-I) stations during each Lagrangian experiment. Vertical profiles of photosynthetically active radiation (PAR) were obtained using a radiometer (Satlantic OCP100FF) deployed every day at midday. Samples for sizefractionated chl a concentration were taken at 5 different depths within the euphotic zone and at one extra depth below the euphotic zone (Fig. 4).

Size-fractionated $\mathbf{c h l}$ a. Water samples $(250 \mathrm{ml})$ from 6 depths were filtered sequentially through 2 and $0.2 \mu \mathrm{m}$ polycarbonate filters. After extraction with $90 \%$ acetone at $-20^{\circ} \mathrm{C}$ overnight, chl a fluorescence was determined with a TD-700 Turner Designs fluorometer calibrated with pure chl $a$.

Picophytoplankton and bacterial biomass. The abundance of picophytoplankton groups (Prochlorococcus, Synechococcus and picoeukaryotes) was determined in $0.6 \mathrm{ml}$ fresh samples using a FACSCalibur flow cytometer (Becton-Dickinson) equipped with a laser emitting at $488 \mathrm{~nm}$. The autotrophic groups were identified on the basis of their relative red and orange fluorescence, and side scatter (SSC) signals. Total bacterial counts were estimated from samples $(1.8 \mathrm{ml})$ preserved with $1 \%$ paraformaldehyde and $0.05 \%$ glutaraldehyde, and frozen at $-80^{\circ} \mathrm{C}$ until analysis within the flow cytometer.

Two groups of heterotrophic bacteria (low nucleic acid [LNA] and high nucleic acid [HNA] content bacteria) were routinely distinguished based on their relative green fluorescence and SSC signals as explained in Gasol \& del Giorgio (2000) and after staining with $2.5 \mathrm{mM}$ DMSO-diluted SYBR Green I DNA fluorochrome (Molecular Probes, ref. S-7563). Prochlorococcus counts from the unstained samples (Morán et al. 2004) were subtracted from HNA bacterial counts in surface samples due to overlapping signals.

Three empirical calibrations between SSC and cell diameter $(\mu \mathrm{m})$ using the sequential filtration method described in Zubkov et al. (1998) were used to estimate biovolume $(\mathrm{Bv})$ for cyanobacteria $(\mu \mathrm{m}=1.0049 \times \mathrm{SSC}+$ $\left.0.6297, \mathrm{r}^{2}=0.47, \mathrm{n}=10\right)$, picoeukaryotes $(\mu \mathrm{m}=0.5389 \times$ $\mathrm{SSC}+0.753, \mathrm{r}^{2}=0.87, \mathrm{n}=17$ ) and bacterioplankton cells $\left(\mu \mathrm{m}=0.7871 \times \mathrm{SSC}+0.4654, \mathrm{r}^{2}=0.60, \mathrm{n}=16\right)$. Lastly, for autotrophic groups Bv was converted into

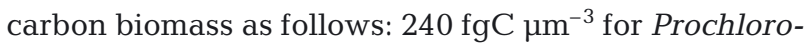

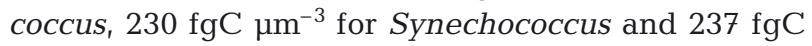
$\mu^{-3}$ for picoeukaryotes. Synechococcus biomass was very low during both Lagrangian studies $(<0.5 \mathrm{mg}$ $\mathrm{m}^{-3}$ ). Heterotrophic bacterial biomass was calculated using an allometric relationship, namely bacterial biomass $\left(\mathrm{fgC} \mathrm{cell}^{-1}\right)=108.8 \times \mathrm{Bv}^{0.898}$ Gundersen et al. (2002).

Size-fractionated in vivo ETS activity rates. Samples for in vivo ETS incubations were taken every 4 to $30 \mathrm{~h}$ to characterize temporal variability in microbial plankton respiration. Two intensive samplings (4 incubations per day) were carried out during each Lagrangian study, in order to analyze the intra-day variability. At each of the 12 stations per Lagrangian study, four $300 \mathrm{ml}$ dark bottles were filled with water from each of the 5 different depths (Fig. 5). One bottle was immediately fixed by adding formaldehyde $(2 \% \mathrm{w} / \mathrm{v}$ final concentration) and used as a killed control. The remaining 3 replicates were inoculated with a sterile solution of $7.9 \mathrm{mM}$ INT to a final concentration of $0.2 \mathrm{mM}$ INT. Samples were incubated for 3 to $5.5 \mathrm{~h}$ in dark conditions (INT is photosensitive) in an on-deck incubator and at in situ temperature. Seawater temperature was controlled by pumping refrigerated surface seawater into the incubator. After incubation, samples were fixed by adding formaldehyde in the same way as for the killed control. Fixed samples were filtered sequentially through 0.8 and $0.2 \mu \mathrm{m}$ pore size polycarbonate filters and processed as described in detail by Martínez-García et al. (2009). Briefly, INT-F was extracted in $1 \mathrm{ml}$ of propanol by sonicating for 20 to $30 \mathrm{~min}$ in $50^{\circ} \mathrm{C}$ water using an ultrasonic bath. Next, $1 \mathrm{ml}$ of the propanol extract containing the INT-F was transferred to $1.5 \mathrm{ml}$ microfuge vials and then centrifuged at $13200 \times g$ for $10 \mathrm{~min}$ at $18^{\circ} \mathrm{C}$. The absorbance of the supernatant was measured at $485 \mathrm{~nm}$ using a spectrophotometer (Shimadzu ISR-240A), and INT-F concentration was calculated by applying a standard curve previously determined using different concentrations of pure INT-F. The percentage of standard error $([\mathrm{SE} / \mathrm{mean}] \times 100)$ for ETS activity measurements averaged $17 \%$.

Total microbial plankton ETS activity was estimated as the sum of the ETS activity in the 0.2 and $0.8 \mu \mathrm{m}$ filters. The contribution of bacteria to total microbial plankton ETS activity was estimated as the percentage of ETS activity in the $<0.8 \mu \mathrm{m}$ size-fraction.

It is important to note that $34 \%$ of the total ETS activity data have been previously used in Martínez-García et al. (2009) with the only aim of comparing ETS activity data with concomitant oxygen consumption data.

Statistical analysis. Data were log- or arcsine-transformed in order to attain normality. The unpaired $t$-test was used for comparisons of dataset pairs. 

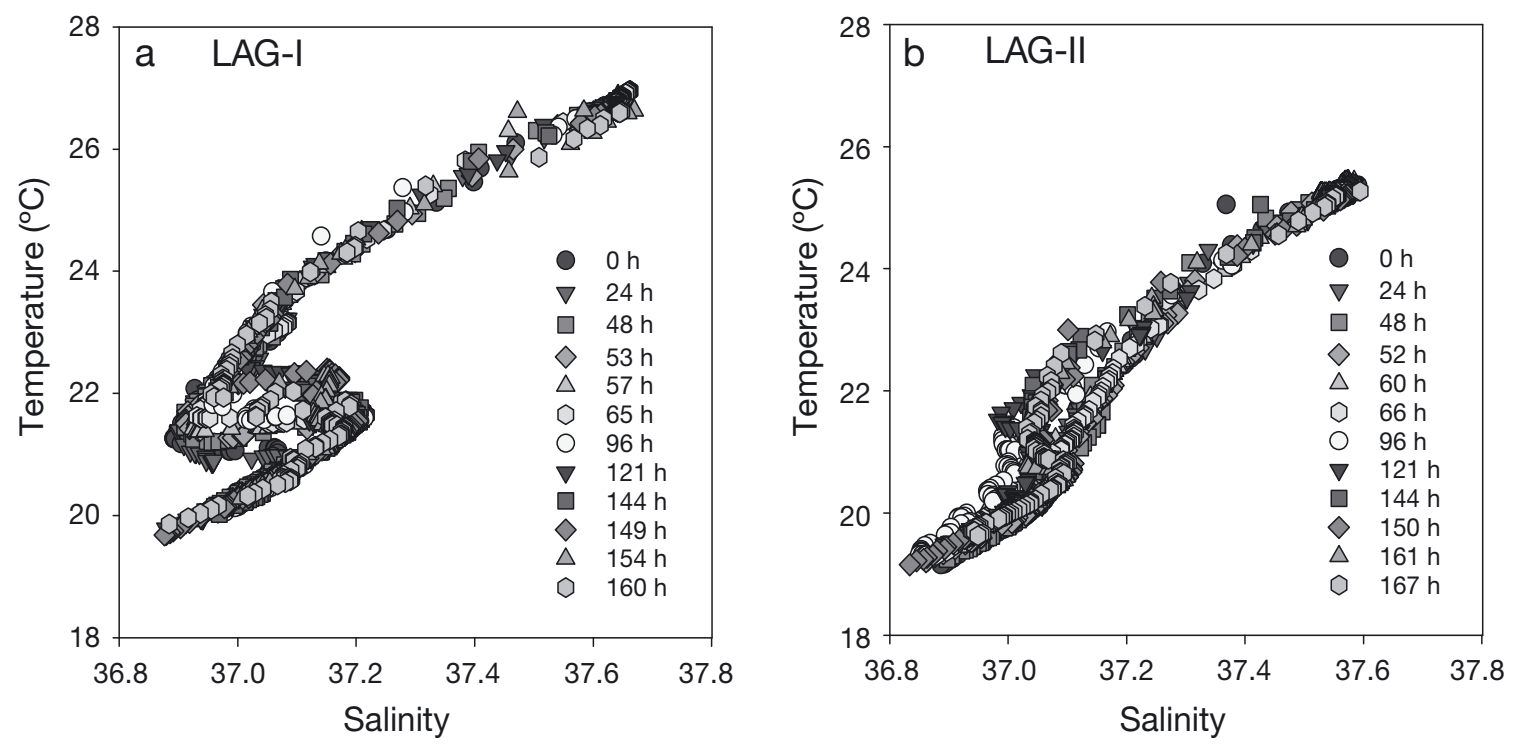

Fig. 2. Temperature-salinity diagram for the upper $150 \mathrm{~m}$ throughout the 2 Lagragian experiments: (a) LAG-I, (b) LAG-II
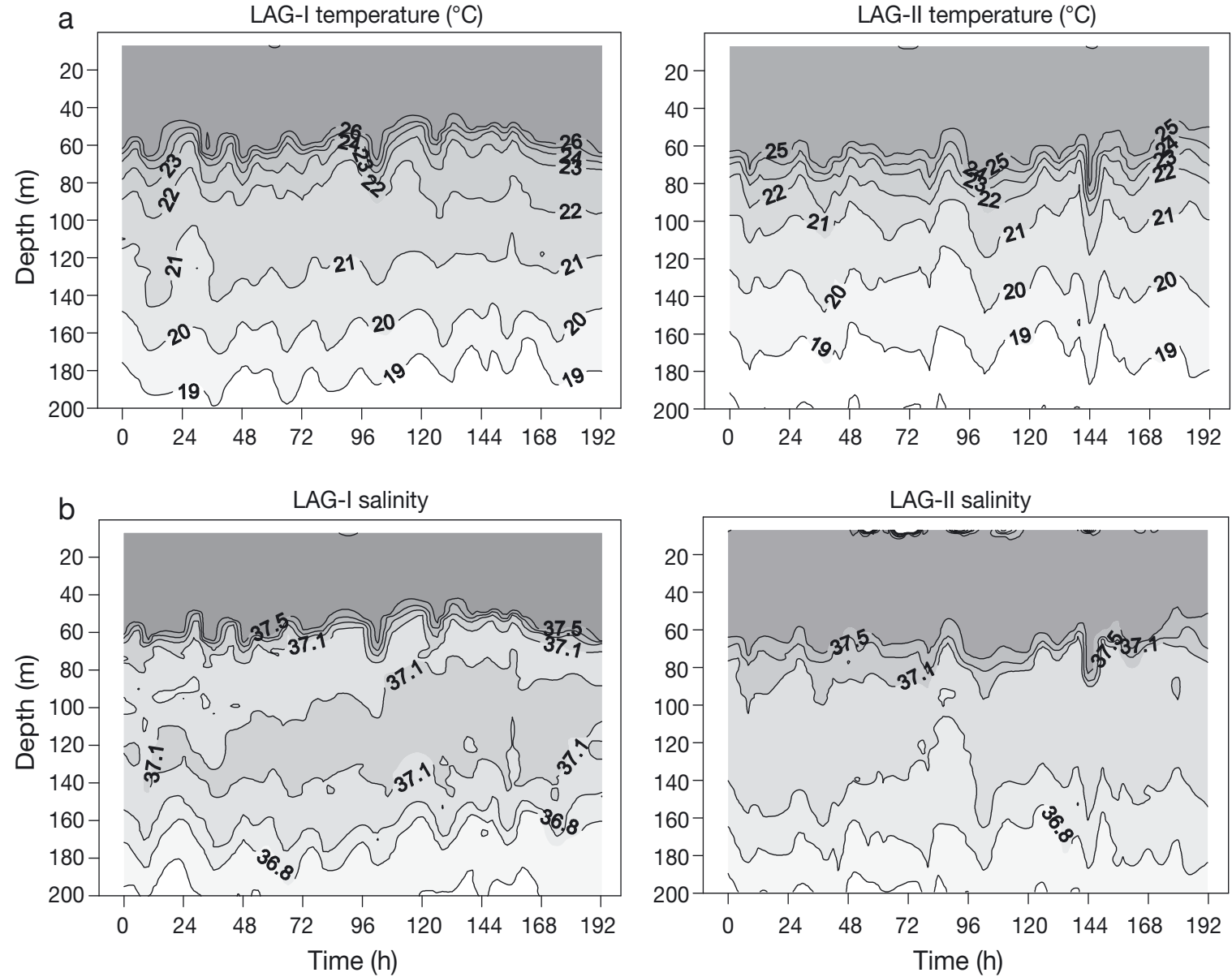

Fig. 3. Time course of the vertical distribution of (a) temperature $\left({ }^{\circ} \mathrm{C}\right.$ ) and (b) salinity during Lagrangian study I (LAG-I, at the center of the North Atlantic Subtropical Gyre) and Lagrangian study II (LAG-II, in the eastern margin of the North Atlantic Subtropical Gyre) 

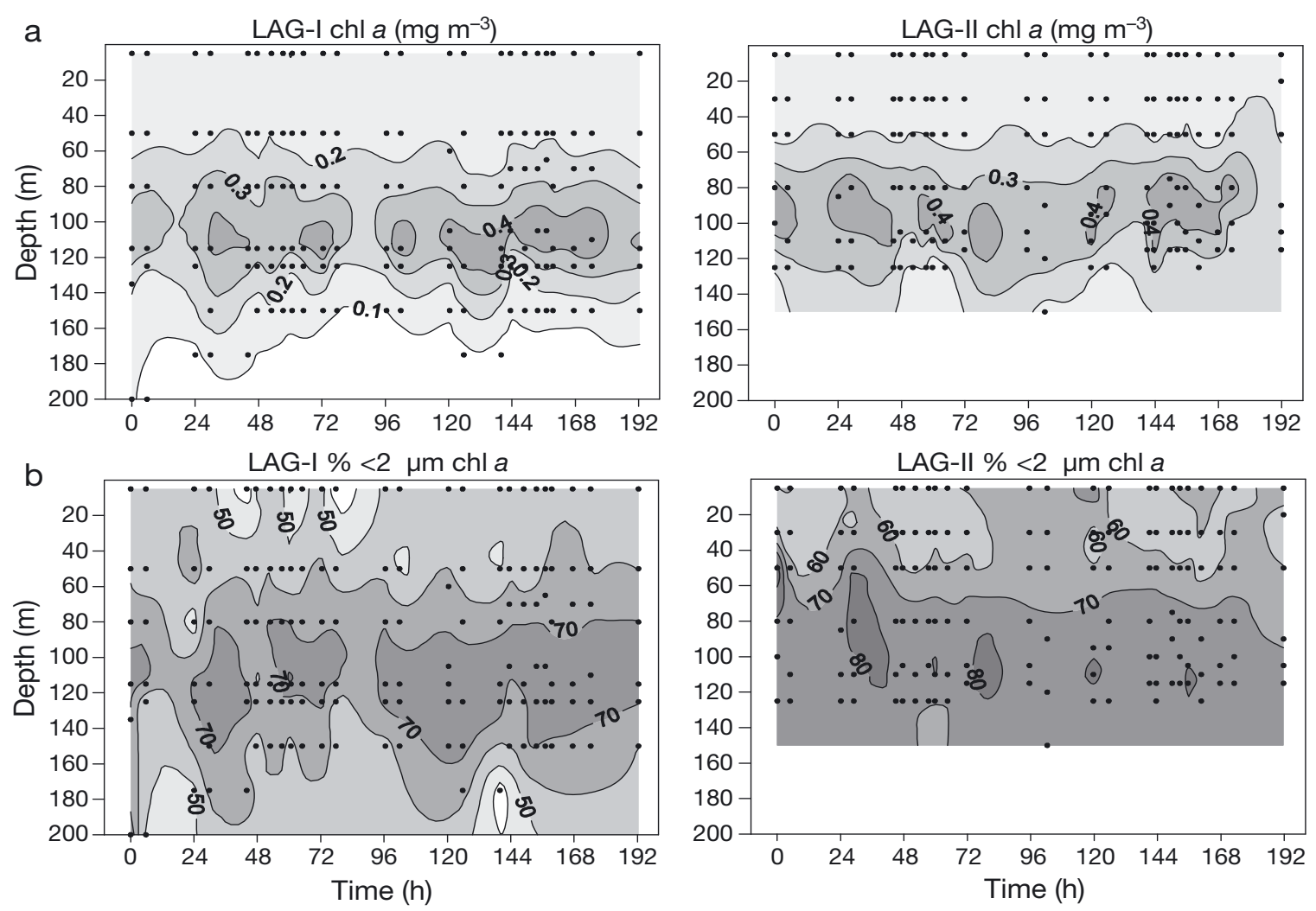

Fig. 4. Time course of the vertical distribution of (a) chlorophyll a ( $\mathrm{chl} \mathrm{a}$ ) concentration $\left(\mathrm{mg} \mathrm{m}^{-3}\right)$ and (b) the \% contribution of picophytoplankton $(<2 \mu \mathrm{m}$ size-fraction) to total chl a concentration during Lagrangian study I (LAG-I, at the center of the North Atlantic Subtropical Gyre) and Lagrangian study II (LAG-II, in the eastern margin of the North Atlantic Subtropical Gyre)

\section{RESULTS}

\section{Hydrographic conditions}

Thermal stratification was present during both Lagrangian studies (Fig. 3). Mean temperature in the upper mixed layer ( 0 to $50 \mathrm{~m}$ ) and at the base of the euphotic zone (mean \pm SE: $121 \pm 7 \mathrm{~m}$ in LAG-I and $112 \pm 6 \mathrm{~m}$ in LAG-II) was 26 and $21^{\circ} \mathrm{C}$ and 25 and $22^{\circ} \mathrm{C}$ during LAG-I and LAG-II, respectively. The location of the thermocline showed periodic displacements of up to $25 \mathrm{~m}$, associated with internal waves.

\section{Size-fractionated chl a concentration}

Chl a concentration showed relatively low temporal variability (Fig. 4). The vertical distribution of chl a was characterized by low concentrations (on average 0.14 and $0.16 \mathrm{mg} \mathrm{m}^{-3}$ during LAG-I and LAG-II, respectively) in the upper mixed layer (UML) and the presence of a deep chlorophyll maximum (DCM), located between 80 and $135 \mathrm{~m}$ in LAG-I and between 70 and $115 \mathrm{~m}$ in LAG-II, where chl a concentration was higher than $0.3 \mathrm{mg} \mathrm{m}^{-3}$ (Fig. 4).
The mean contribution of picophytoplankton to total chl a (\% chl $a<2 \mu \mathrm{m})$ was significantly lower in LAG-I $(64 \%)$ than in LAG-II (69\%) ( $t$-test, p = 0.005) (Fig. 4). The $\%$ chl $a<2 \mu \mathrm{m}$ was lower in the UML (on average 56 and $64 \%$ in LAG-I and LAG-II, respectively) than in the DCM layer (on average 69 and $75 \%$ in LAG-I and LAG-II, respectively).

\section{Size-fractionated in vivo ETS activity rates}

Total in vivo microbial plankton ETS activity rates (expressed as rates of INT-F formation, $\mu$ mol INT-F $\mathrm{m}^{-3} \mathrm{~h}^{-1}$ ) showed considerable temporal variability (Fig. 5). ETS activity rates decreased with depth and ranged from 0.02 to $1.93 \mu$ mol INT-F $\mathrm{m}^{-3} \mathrm{~h}^{-1}$ in LAG-I and from 0.04 to $2.42 \mu \mathrm{mol}$ INT-F $\mathrm{m}^{-3} \mathrm{~h}^{-1}$ in LAG-II. Mean ETS activity rate was significantly lower in LAG-I than in LAG-II ( $t$-test, $\mathrm{p}<0.001)$. Applying an empirical R:ETS ratio of 12.8 derived from nonaxenic phytoplankton cultures (see Martínez-García et al. 2009), and assuming a respiration quotient of 1 , microbial plankton respiration ranged from 0.004 to $0.30 \mathrm{mgC} \mathrm{m}^{-3} \mathrm{~h}^{-1}$ in LAG-I and from 0.006 to $0.37 \mathrm{mgC} \mathrm{m}^{-3} \mathrm{~h}^{-1}$ in LAG-II. Euphotic 

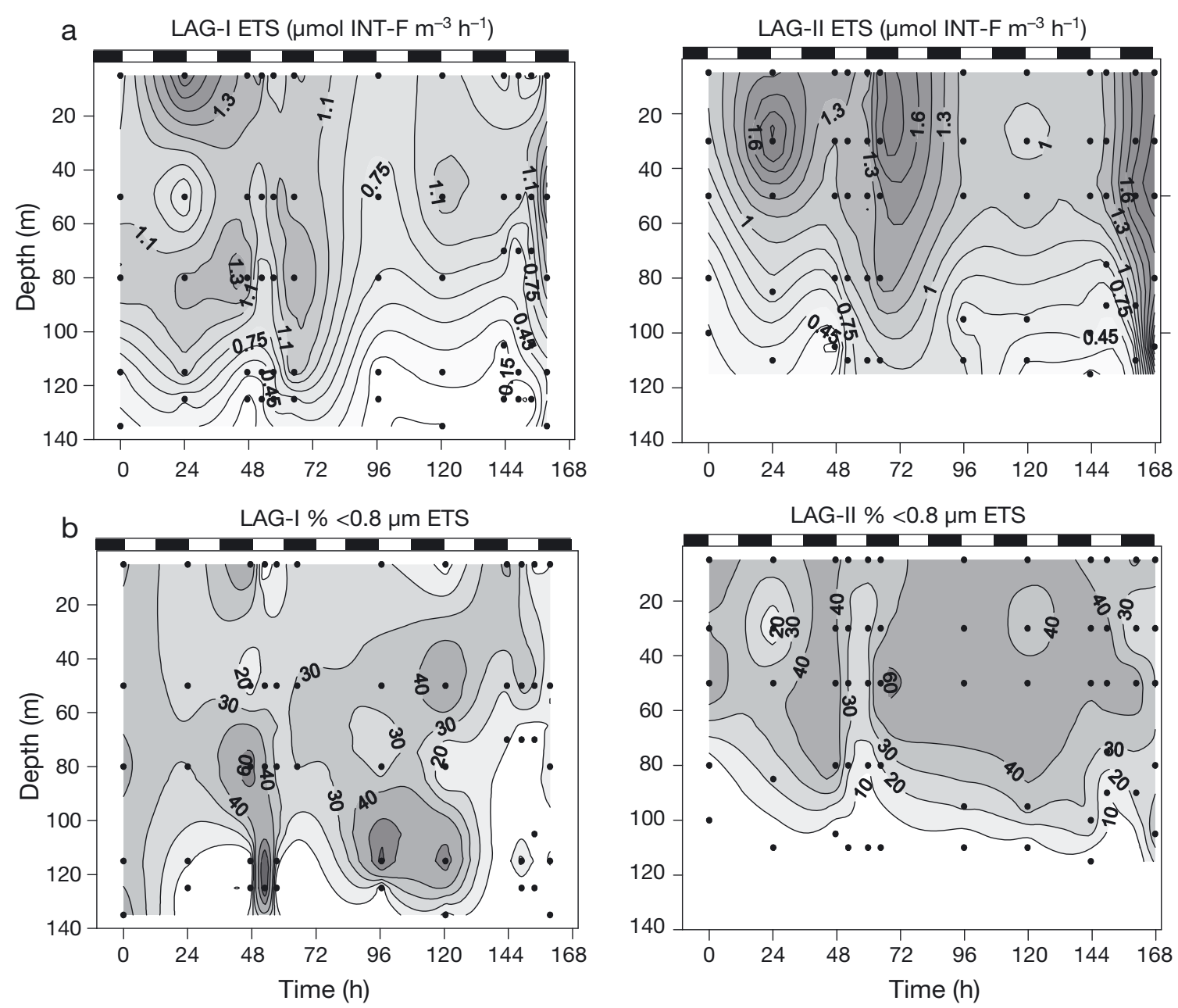

Fig. 5. Time course of the vertical distribution of (a) in vivo electron transport system (ETS) activity rates ( $\mu$ mol INT-F $\left.\mathrm{m}^{-3} \mathrm{~h}^{-1}\right)$ and (b) the contribution of $<0.8 \mu \mathrm{m}$ size-fraction (\%) to total ETS activity during Lagrangian study I (LAG-I, at the center of the North Atlantic Subtropical Gyre) and Lagrangian study II (LAG-II, in the eastern margin of the North Atlantic Subtropical Gyre). Black bars on top indicate the dark periods

depth-integrated total in vivo ETS activity was not significantly different between LAG-I and LAG-II (Fig. 6). The estimated mean \pm SD euphotic zone depth-integrated microbial plankton respiration was $17 \pm 5 \mathrm{mgC} \mathrm{m}^{-2} \mathrm{~h}^{-1}$ for LAG-I and $19 \pm 6 \mathrm{mgC} \mathrm{m}^{-2}$ $\mathrm{h}^{-1}$ for LAG-II.

The contribution of the $<0.8 \mu \mathrm{m}$ size-fraction to total ETS activity (\% ETS $<0.8 \mu \mathrm{m}$ ) widely varied from $<10$ to ca. $90 \%$ at discrete depths, and mean \pm SD values did not significantly differ between LAG-I $(28 \pm 20 \%)$ and LAG-II (33 $\pm 17 \%)$. This contribution was significantly higher in the UML ( $34 \%$ ) than in the DCM layer $(20 \%)$ ( $t$-test, $\mathrm{p}<0.001)$. Mean $( \pm \mathrm{SE}) \%$ ETS $<0.8 \mu \mathrm{m}$ in the UML was significantly lower in LAG-I ( $26 \pm 3 \%)$ than in LAG-II $(39 \pm 2 \%)(t$-test, $\mathrm{p}<0.001)$. By contrast, no significant differences were found in the DCM layer between LAG-I $(26 \pm 4 \%)$ and LAG-II $(20 \pm 3 \%)(t$-test, $\mathrm{p}=0.19)$.

\section{Temporal variability of size-fractionated in vivo ETS activity}

The drifter buoys did not significantly deviate from the expected trajectories; therefore, it can be assumed that the same water masses were sampled throughout the studies. The inter-day variability was assessed by calculating the percentage of error of the mean ETS activity rate from samples collected during different days but at approximately the same time (dawn $\pm 1.5 \mathrm{~h}$; $\mathrm{n}=6$ in LAG-I, $\mathrm{n}=7$ in LAG-II). The intra-day variability was estimated from the percentage of error of the mean ETS activity rate from samples collected within the same day but at different times. Given the clear vertical variations, we analyzed data from the UML and the DCM layer separately. Overall inter-day variability was lower in the in UML $8 \%$ in LAG-I and $9 \%$ in LAG-II) than in the DCM layer (18\% in LAG-I and 

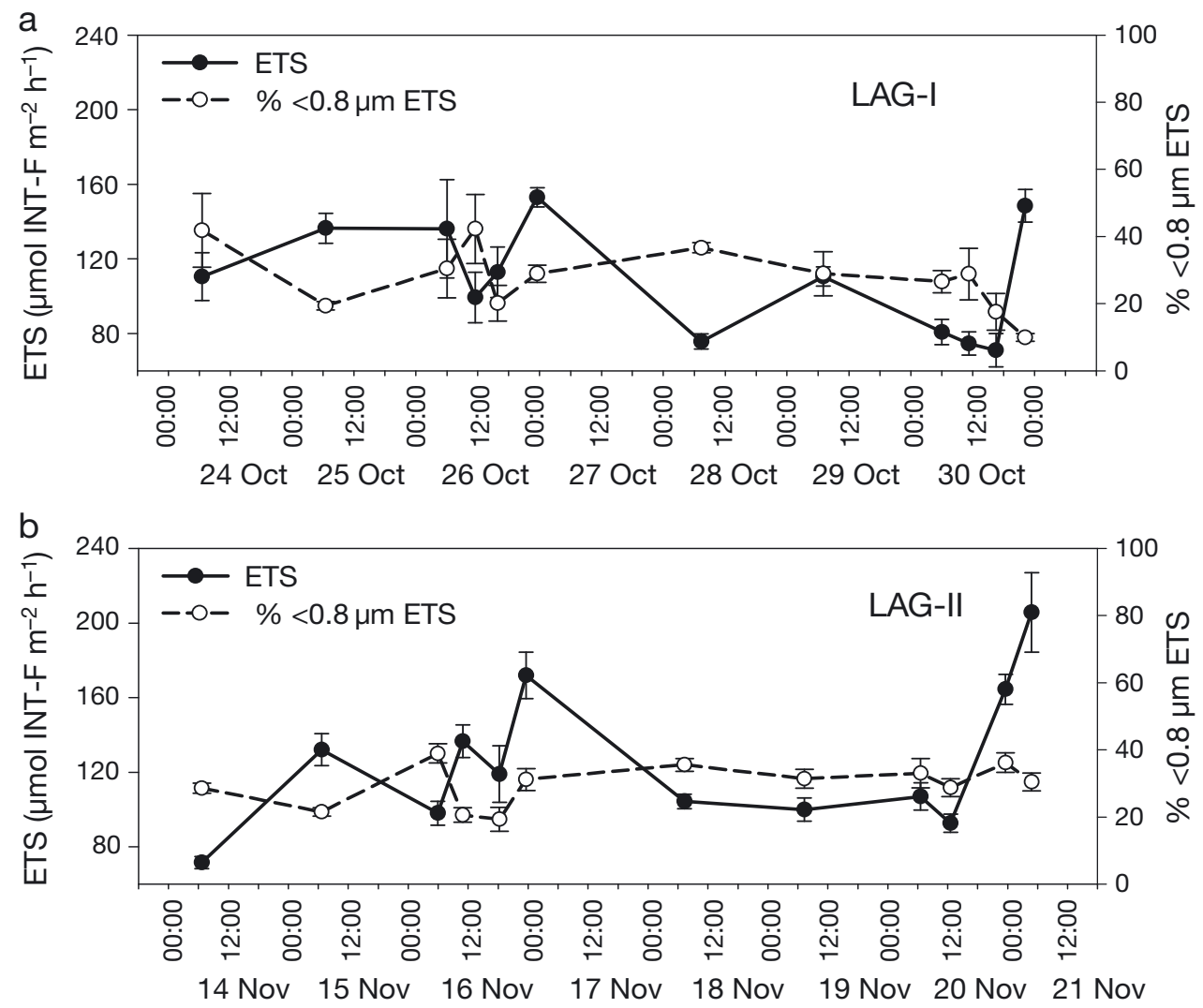

Fig. 6. Time course of euphotic depth-integrated in vivo electron transport system (ETS) activity rates ( $\mu$ mol INT-F $\mathrm{m}^{-2} \mathrm{~h}^{-1}$ ) and the contribution of $<0.8 \mu \mathrm{m}$ size-fraction (\%) to total integrated ETS activity during (a) Lagrangian study I (LAG-I, at the center of the North Atlantic Subtropical Gyre) and (b) Lagrangian study II (LAG-II, in the eastern margin of the North Atlantic Subtropical Gyre). Error bars indicate standard errors

$29 \%$ in LAG-II). The intra-day variability was in the same range as that of the inter-day variability both in the UML $(13 \pm 1 \%$ in LAG-I and $10.7 \pm 0.1 \%$ in LAGII) and the DCM layer $(18.6 \pm 0.3 \%$ in LAG-I and $27 \pm$ $1 \%$ in LAG-II). In order to further explore the observed intra-day variability, we analyzed all the ETS data collected during each Lagrangian study, classifying each sampling point into a 'night' (water collected between dusk and dawn) or 'day' (water collected between dawn and dusk) category depending on the sampling time (Fig. A1 in Appendix 1, Table 1).

There were significant differences in the DCM layer during both Lagrangian studies, whereas significant differences among day and night samples from the UML were found only in LAG-II. Chl $a$ and \% chl $a$ $<2 \mu \mathrm{m}$ did not significantly vary between day and night in the UML or in the DCM layer (Table 1). Similarly, there were no significant changes between day and night for the biomass of some major components of the microbial plankton community: bacteria, Prochlorococcus and picoeukaryotic phytoplankton (Table 1). Despite the aforementioned inter-day variability, an apparent diel pattern emerged when plotting euphotic zone depth-integrated in vivo ETS activity rates according to the sampling time, both in LAG-I and LAG-II (Fig. 7). Euphotic zone depth-integrated ETS activity was significantly higher for samples collected

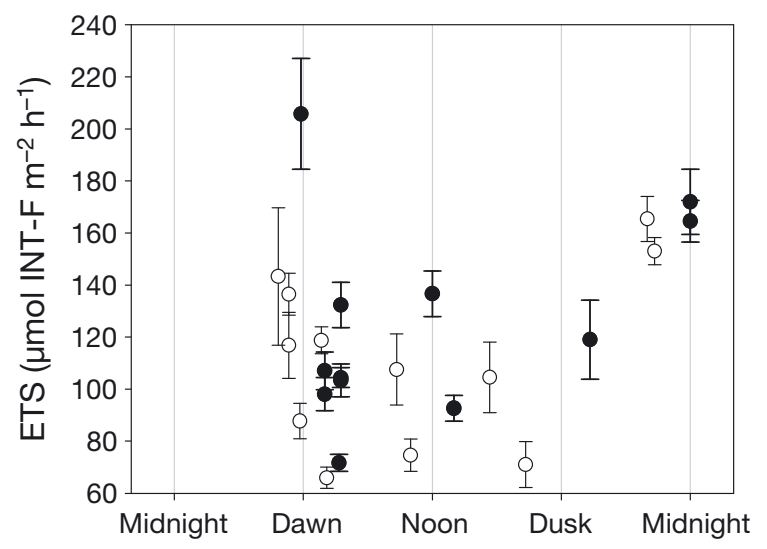

Fig. 7. Mean euphotic zone depth-integrated in vivo electron transport system (ETS) activity rates ( $\mu \mathrm{mol}$ INT-F $\mathrm{m}^{-2} \mathrm{~h}^{-1}$ ) at different times of the day during Lagrangian study I (LAG-I, O) and Lagrangian study II (LAG-II, ๑). Error bars indicate the standard error 
Table 1. Mean ( \pm SE) day and night chlorophyll a (chl a) concentration (chl a), percentage of chl $a$ in the $<2 \mu \mathrm{m}$ fraction $(\mathrm{chl} a<2)$, bacterial biomass (BB), Prochlorococcus biomass (ProcB), picoeukaryotic biomass (pEukB), total in vivo electron transport system (ETS) activity, $<0.8 \mu \mathrm{m}$ size-fraction in vivo ETS activity (ETS $<0.8),>0.8 \mu \mathrm{m}$ size-fraction in vivo ETS activity (ETS $>0.8$ ), in the upper mixed layer (UML, 0 to $50 \mathrm{~m}$ ) and in the deep chlorophyll maximum (DCM) layer (70 to $135 \mathrm{~m}$ ) during Lagrangian study I (LAG-I) and II (LAG-II). Significant differences between day and night means were determined using $t$-test. ns $=$ not significant

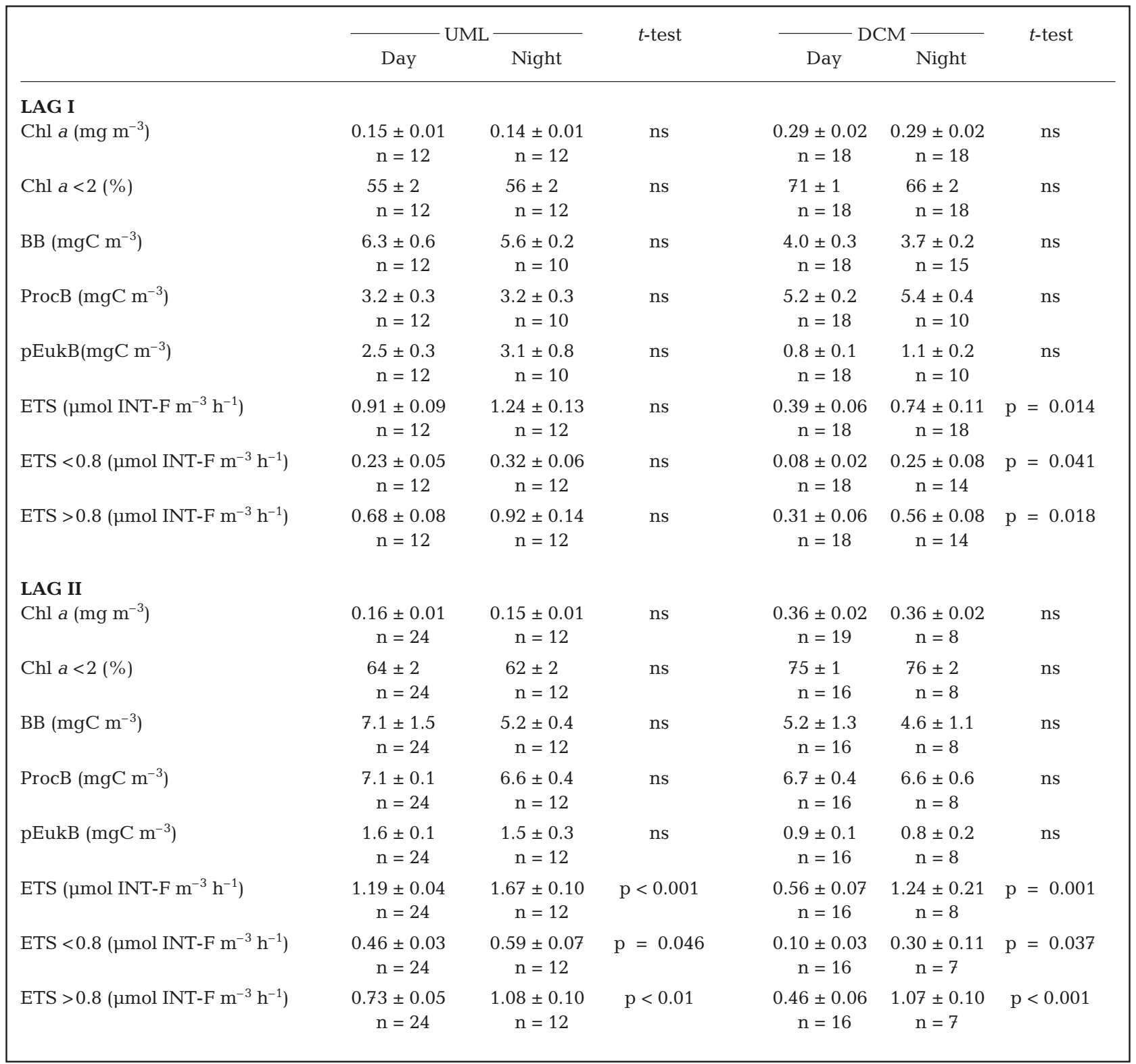

at night than during the day ( $t$-test, $\mathrm{p}=0.015)$. Averaging integrated hourly ETS activity rates on Fig. 7 and assuming a constant respiration rate over $24 \mathrm{~h}$, we obtained a mean $( \pm \mathrm{SE})$ daily euphotic zone depthintegrated ETS activity rate of $2856 \pm 172 \mu \mathrm{mol}$ INT-F $\mathrm{m}^{-2} \mathrm{~d}^{-1}$, which is equivalent to a microbial plankton respiration of $439 \pm 26 \mathrm{mgC} \mathrm{m}^{-2} \mathrm{~d}^{-1}$. However, the high intra-day variability indicates that the daily euphotic depth-integrated ETS activity rate could be biased depending on the sampling time.

\section{DISCUSSION}

The estimation of microbial respiration rates in oligotrophic waters of the North Atlantic Subtropical Gyre has promoted a long-lasting scientific controversy. Microbial respiration rates, extrapolated from direct measurements (by dark bottle incubations), suggest net heterotrophy in the euphotic zone (Duarte et al. 1999, Serret et al. 2001), whereas geochemical evidence (based on inorganic carbon, nutri- 
ent and dissolved oxygen concentration data in the euphotic layer or integrated sediment trap data) indicates that the upper ocean is a net source of oxygen to the atmosphere (Karl et al. 2003, Álvarez \& Álvarez-Salgado 2007, Riser \& Johnson 2008). Recent studies point to a possible overestimation of microbial respiration rates as derived from oxygen consumption experiments (Marañón et al. 2007, Morán et al. 2007). The most common approach to measure community respiration consists of sampling and confining a microbial plankton population before dawn and subsequently incubating during $24 \mathrm{~h}$ in the dark. How the exclusion of the diel dynamics of plankton organisms in the euphotic zone affects microbial plankton respiration estimates remains poorly understood, particularly in open ocean waters. The in vivo ETS method (Martínez-García et al. 2009) reduces incubation time to 3 to $5.5 \mathrm{~h}$. Using this method, we could evaluate the intra-day variability of microbial plankton respiration in the euphotic zone of the oligotrophic North Atlantic Subtropical Gyre during 4 intensive samplings (4 incubations per day), and compare it to inter-day variability. In our 2 Lagrangian studies, both inter- and intra-day variability were high.

The pre-filtration procedure (usually through a $0.8 \mu \mathrm{m}$ filter) commonly used to estimate bacterial respiration has associated problems as well. Among others, separation of the bacterial fraction breaks the trophic links between bacteria and their grazers, organic and inorganic nutrient suppliers, and/or competitors. When bacterial populations are closely controlled by predation, the elimination of grazing pressure by pre-filtration can immediately enhance bacterial growth and consequently overestimate bacterial respiration rates. Robinson (2008) found a linear decrease in oxygen concentration in about $70 \%$ of published time course experiments conducted with size-fractionated water samples, concluding that the effects of pre-filtration must be unimportant. However, a linear decrease in oxygen consumption over 24 to $48 \mathrm{~h}$ does not necessarily imply that bacterial growth enhancement is insignificant, as bacteria may have immediately responded to the relief of grazing pressure. Indeed, several authors report bacterial production increases through the incubations, in spite of a linear decrease in oxygen concentration (see review in Robinson 2008).

The in vivo ETS method (Martínez-García et al. 2009) allowed us to estimate the contribution of bacteria (defined as the percentage of respiration by the $<0.8 \mu \mathrm{m}$ plankton size-fraction) to total microbial plankton respiration, avoiding the pre-filtration procedure and long incubation times.

\section{Bacterial contribution to total microbial community respiration}

The contribution of bacteria to total microbial community respiration as derived from size-fractionated in vivo ETS activity measurements averaged $29 \pm 19$ (SD) \% $(\mathrm{n}=115)$ in North Atlantic subtropical waters. Our value is significantly lower than the $45 \%$ value obtained by Robinson (2008) from size-fractionated incubations ( $t$-test, $\mathrm{p}<0.001)$, but it does not significantly differ from the mean value obtained from biomass calculations $(32 \pm 22$ (SD) \%, Robinson \& Williams 2005) or the $35 \%$ value obtained by Nagata (2000) using a plankton flow model for the oligotrophic ocean. A mean bacterial contribution to community respiration of 30 to $35 \%$ is consistent with the contribution of the other 2 major microbial populations. A recent review by Calbet \& Landry (2004) suggests that microzooplankton respiration can account for a similar proportion of microbial plankton community respiration as that attributed to bacteria. In addition, the contribution of phytoplankton to overall respiration averages $34 \%$, as derived from biomass determinations (Robinson \& Williams 2005).

A great variability in the contribution of bacteria to total community respiration has been found within a particular ecosystem using size-fractioned water sample incubations. The seasonal study by Lemée et al. (2002) in the NW Mediterranean Sea estimated that bacterial respiration accounted for 16 to $159 \%$ of community respiration. In 4 out of 11 sampling stations the bacterial contribution was $>95 \%$ of depth-integrated total microbial respiration, which is highly unrealistic. Excluding these 4 data points, the averaged contribution of bacteria to total respiration would drop from 65 to $35 \%$.

In open ocean waters, the bacterial contribution to total community respiration as derived from size-fractionated water samples is well above any of the aforementioned mean values, ranging from 65 to $78 \%$ (Lemée et al. 2002, González et al. 2003, Alonso-Sáez et al. 2007, Robinson 2008). This very large bacterial contribution to community respiration found in oligotrophic waters has been commonly attributed to an overwhelming dominance of heterotrophic bacteria in the oligotrophic ocean. Alternatively, the high bacterial contribution could be an artifact: a tight coupling between bacteria and protistan grazers in oligotrophic waters could amplify the bacterial response to the release of predation pressure upon pre-filtration. Recent evidence points to a dominance of phytoplankton biomass over bacterial biomass in the oligotrophic ocean (Li \& Harrison 2001, Morán et al. 2004). Moreover, heterotrophic bacteria account only for $20 \%$ of the total microbial plankton biomass in the euphotic layer of the eastern subtropical North Atlantic 
(Marañón et al. 2007). In the latter study, the sum of respiration rates by phytoplankton, heterotrophic protists and bacteria, as estimated from their biomass and metabolic rates, ranged from 402 to $848 \mathrm{mgC} \mathrm{m}^{-2} \mathrm{~d}^{-1}$, of which 11 to $43 \%$ was attributed to bacteria. These values correspond well to our estimates. Therefore, our results strongly suggest that pre-filtration might considerably stimulate bacterial activity during dark bottle incubations, eventually leading to a gross overestimation of bacterial respiration.

The significantly lower contribution of the $<0.8 \mu \mathrm{m}$ size-fraction to the overall ETS activity found in the DCM layer (20\%) compared to the UML (34\%) could be related to an increase in particle abundance below the thermocline. Ghiglione et al. (2007) observed that the percentage of attached bacteria increased from $10 \%$ at $5 \mathrm{~m}$ depth to $30 \%$ in the DCM (50 m depth) in Mediterranean waters during the summer. The methodological limitations posed by particle-attached bacteria are unavoidable when using size-fractionation approaches. Strictly, the contribution of the $<0.8 \mu \mathrm{m}$ size-fraction should be referred to as the contribution of free-bacteria to the total microbial respiration.

\section{Temporal variability in microbial plankton respiration}

Many oceanic phenomena display high short-term variability associated to natural light-dark cycles and changing weather conditions, such as cloud cover and winds, that influence chemical (e.g. dissolved organic matter properties), biological (e.g. metabolic rates, vertical migration) and physical processes (e.g. surface layer mixing) at scales of hours to days. However, the effect of short-term dynamics on microbial plankton respiration has been surprisingly poorly studied in oligotrophic oceanic ecosystems. A positive effect of light on heterotrophic processes like bacterial production and microbial community respiration in coastal zones has been linked to the diel cycle of primary production (Fuhrman et al. 1985, Gasol et al. 1998, Tsai et al. 2005, Pringault et al. 2009).

A closer coupling between phytoplankton and bacterial activity is expected in open ocean oligotrophic waters, where the main source of dissolved organic matter is primary production, than in coastal areas. By contrast, a higher bacterial production during evening and night than during daytime has been observed in subtropical oligotrophic waters (Shiah 1999, Van Wambeke et al. 2008). Van Wambeke et al. (2008) partially related this diel pattern to the detrimental effects of UV radiation on bacterial production during the central hours of the day (Visser et al. 2002, Conan et al. 2008), which might cause a lag between the release of dissolved organic carbon (DOC) by phytoplankton and the consumption of organic matter by bacteria.

UV-B radiation penetrates down to $30 \%$ of the euphotic zone depth in the clearest waters of the central subtropical Atlantic Ocean (Piazena et al. 2002). According to this finding, UV-B would penetrate down to 39 and $35 \mathrm{~m}$ at the locations of LAG-I and LAG-II, respectively. Despite the observed inter-day variability, we measured significantly higher rates of total microbial plankton respiration, as derived from in vivo ETS measurements, in samples collected at night than during the day (Table 1). To the best of our knowledge, there are no comparable studies of short-term variations of microbial respiration in open ocean oligotrophic waters. Given that bacteria contribute a considerable fraction of microbial respiration (Robinson 2008), higher microbial respiration could be directly related to higher bacterial respiration. However, we did not find a clear diel pattern in the contribution of the $<0.8 \mu \mathrm{m}$ size-fraction (bacteria) to total ETS activity; therefore, the increase in ETS activity must be related to both size-fractions (i.e. both bacteria and other microbes). We indeed found that ETS activity in both size-fractions $(<0.8 \mu \mathrm{m}$ and $>0.8 \mu \mathrm{m})$ were significantly higher in samples collected at night than during the day (Table 1). As we mentioned before, particleattached bacteria would be retained by the $0.8 \mu \mathrm{m}$ filter. Strong detrimental effects caused by sunlight have been observed on Prochlorococcus growth in very oligotrophic waters (Vaulot \& Marie 1999). Most Prochlorococcus cells would also be retained in the $0.8 \mu \mathrm{m}$ filter, as their mean diameter during the Lagrangian studies was $0.78 \mu \mathrm{m}$ (A. Calvo-Díaz pers. comm.). However, we did not observe significant changes either in bacterial, Prochlorococcus or total phytoplankton biomass (Table 1), which suggests a strong top-down control of their standing stocks. Unfortunately, we lack information about microzooplankton biomass in our study, which has been estimated to contribute up to $20 \%$ to total microbial biomass (which includes bacteria, phytoplankton and microzooplankton) in this oceanic province (Marañón et al. 2007).

It is important to note that despite water sample collections occurring either at night or during the day, ETS activity measurements were conducted in dark conditions (see the 'Materials and methods' section), and thus a potential positive effect of concomitant release of recently fixed carbon by autotrophs would not have been taken into account. However, studies in oligotrophic areas indicate that microbial plankton community respiration in light conditons is not significantly different from respiration in the dark (Grande et al. 1989, González et al. 2008).

Nevertheless, if sunlight was the only factor governing the observed variability in microbial respiration, 
then the effect should be less evident in the DCM layer ( 70 to $135 \mathrm{~m}$ ) than in the UML (0 to $50 \mathrm{~m}$ ). We found significantly higher respiration rates at night than during the day both in the UML and DCM layer, which suggests that other factors must be influencing the observed intra-day variability. Van Wambeke et al. (2008) also reported nocturnal bacterial production maxima down to $155 \mathrm{~m}$ in the South Pacific Gyre, but did not provide an explanation for their findings. Kuipers et al. (2000) demonstrated that bacterioplankton growth in the euphotic layer of the subtropical Atlantic is limited by the supply of $\mathrm{N}$ and P during the day. This limited supply is likely due to direct competition with phytoplankton, and was not observed during the night, thus leading to a diel phasing between DOC release by phytoplankton and bacterial consumption (Kuipers et al. 2000). Similarly, Shiah (1999) demonstrated that UV radiation was not required to explain the higher bacterial production at night, as he incubated natural microbial plankton populations in UVabsorbing carboys. Instead, Shiah (1999) proposed topdown control processes as potential additional factors affecting bacterioplankton diel variability.

Other authors have suggested that night-time stimulation of bacterial production might be a consequence of diel zooplankton migration (Simon 1994, Torréton et al. 1994). Harrison et al. (2001) measured higher mesozooplankton biomass at night than during the day in the euphotic zone of the subtropical North Atlantic Ocean in autumn. Zooplankton produce a large quantity of fecal pellets by intensive feeding on phytoplankton in the productive layer at night (Ghiglione et al. 2007). The solubilization of these organic aggregates and the release of dissolved matter could enhance microbial respiration rates during the night.

In summary, we have shown that bacterioplankton respiration might have been consistently overestimated in the oligotrophic ocean as a consequence of the commonly used pre-filtration methods, which would translate into a significant underestimation of the bacterial growth efficiency in the oligotrophic ocean. Our results also indicate that significant bias in microbial plankton respiration rates emerges when short-term temporal variability is not taken into account. In particular, the effect of diel cycles on microbial plankton respiration should be adequately explored over a range of marine ecosystems if we aim at better constraining the oceanic carbon cycle.

Acknowledgements. We thank all the people involved in the project CARPOS who helped with the preparation and sampling of the cruise, particularly the principal investigator R. Varela. We are indebted to the GOFUVI research group (University of Vigo), who provided the CTD data. We also thank the captain and crew on board the BIO 'Hespérides'. This research was supported by a CICYT contract (REN2003-
06633-C03) and a European Community Marie Curie Reintegration Fellowship (MERG-CT-2004-511937). S.M-G. was funded by a FPU MEC fellowship. E.T. was funded by a Juan de la Cierva and a Ramón y Cajal-MEC contract.

\section{LITERATURE CITED}

Alonso-Sáez L, Gasol JM, Arístegui J, Vilas JC, Vaqué D, Duarte CM, Agustí S (2007) Large-scale variability in surface bacterial carbon demand and growth efficiency in the subtropical northeast Atlantic Ocean. Limnol Oceanogr 52:533-546

Álvarez M, Álvarez-Salgado XA (2007) Biogeochemical budgets in the eastern boundary current system of the North Atlantic: evidence of net heterotrophy and nitrogen fixation. Limnol Oceanogr 52:1328-1335

Bettarel Y, Dolan JR, Hornak K, Lemée R and others (2002) Strong, weak, and missing links in a microbial community of the NW Mediterranean Sea. FEMS Microbiol Ecol 42: $451-462$

Calbet A, Landry MR (2004) Phytoplankton growth, microzooplankton grazing, and carbon cycling in marine systems. Limnol Oceanogr 49:51-57

> Claustre H, Huot Y, Obernosterer I, Gentili B, Tailliez D, Lewis M (2008) Gross community production and metabolic balance in the South Pacific Gyre, using a non intrusive bio-optical method. Biogeosciences 5:463-474

Conan P, Joux F, Torréton JP, Pujo-Pay M, Douki T, RochelleNewall E, Mari X (2008) Effect of solar ultraviolet radiation on bacterio- and phytoplankton activity in a large coral reef lagoon (shouthwest New Caledonia). Aquat Microb Ecol 52:83-98

Duarte CM, Agustí S, del Giorgio PA, Cole JJ (1999) Regional carbon imbalances in the oceans. Science 284:1735b

Fuhrman JA, Eppley RW, Hagström A, Azam F (1985) Diel variations in bacterioplankton, phytoplankton, and related parameters in the Southern California Bight. Mar Ecol Prog Ser 27:9-20

Gasol JM, del Giorgio PA (2000) Using flow citometry for counting natural planktonic bacteria and understanding the structure of planktonic bacterial communities. Sci Mar 64: 197-224

Gasol JM, Doval MD, Pinhassi J, Calderón-Paz JI, GuixaBoixareu N, Vaqué D, Pedrós-Alió C (1998) Diel variations in bacterial heterotrophic activity and growth in the northwestern Mediterranean Sea. Mar Ecol Prog Ser 164: $107-124$

Gattuso JP, Peduzzi S, Pizay MD, Tonolla M (2002) Changes in freshwater bacterial community composition during measurements of microbial and community respiration. J Plankton Res 24:1197-1206

Ghiglione JF, Mevel G, Pujo-Pay M, Mousseau L, Lebaron P, Goutx M (2007) Diel and seasonal variations in abundance, activity, and community structure of particleattached and free-living bacteria in NW Mediterranean Sea. Microb Ecol 54:217-231

González N, Anadón R, Viesca L (2003) Carbon flux through the microbial community in a temperate sea during summer: role of bacterial metabolism. Aquat Microb Ecol 33: $117-126$

> González N, Gatusso JP, Middelburg JJ (2008) Oxygen production and carbon fixation in oligotrophic coastal bays and the relationship with gross and net primary production. Aquat Microb Ecol 52:119-130

> Grande KD, Williams PJleB, Marra J, Purdie DA, Heinemann K, Eppley RW, Bender ML (1989) Primary production in 
the North Pacific gyre: a comparison of rates determined by the ${ }^{14} \mathrm{C}, \mathrm{O}_{2}$ concentration and ${ }^{18} \mathrm{O}$ methods. Deep-Sea Res Part A 36:1621-1634

> Gundersen K, Heldal M, Norland S, Purdie DA, Knap AN (2002) Elemental C, N, and P cell content of individual bacteria collected at the Bermuda Atlantic Time-series Study (BATS) site. Limnol Oceanogr 47:1525-1530

Harrison WG, Arístegui J, Head EJH, Li WKW, Longhurst AR, Sameoto DD (2001) Basin-scale variability in plankton biomass and community metabolism in the sub-tropical North Atlantic Ocean. Deep-Sea Res II 48:2241-2269

Kaiser E, Herndl GJ (1997) Rapid recovery of marine bacterioplankton activity after inhibition by UV radiation in coastal waters. Appl Environ Microbiol 63:4026-4031

Karl DM, Laws EA, Morris P, Williams PJ le B, Emerson S (2003) Metabolic balance of the open sea. Nature 426:32

Kuipers B, van Noort GJ, Vosjan J, Herndl GJ (2000) Diel periodicity of bacterioplankton in the euphotic zone of the subtropical Atlantic Ocean. Mar Ecol Prog Ser 201:13-25

Lemée R, Rochelle-Newall E, Van Wambeke F, Pizay MD, Rinaldi P, Gatusso, JP (2002) Seasonal variation of bacterial production, respiration and growth efficiency in the open NW Mediterranean Sea. Aquat Microb Ecol 29: 227-237

Li WKW, Harrison WG (2001) Chlorophyll, bacteria and picophytoplankton in ecological provinces of the North Atlantic. Deep-Sea Res II 48:2271-2293

Malone TC, Ducklow HW, Peele ER, Pike SE (1991) Picoplankton carbon flux in Chesapeake Bay. Mar Ecol Prog Ser 78:11-22

Marañón E, Pérez V, Fernández E, Anadón R and others (2007) Planktonic carbon budget in the eastern subtropical North Atlantic. Aquat Microb Ecol 48:261-275

Martínez-García S, Fernández E, Aranguren-Gassis M, Teira E (2009) In vivo electron transport system activity: a method to estimate respiration in natural marine microbial planktonic communities. Limnol Oceanogr Methods 7: 459-469

- Massana R, Pedrós-Alió C, Casamayor EO, Gasol JM (2001) Changes in marine bacterioplankton phylogenetic composition during incubations designed to measure biogeochemically significant parameters. Limnol Oceanogr 46: $1181-1188$

Morán XAG, Fernández E, Pérez V (2004) Size-fractionated primary production, bacterial production and net community production in subtropical and tropical domains of the oligotrophic NE Atlantic in autumn. Mar Ecol Prog Ser 274:17-29

- Morán XAG, Pérez V, Fernández E (2007) Mismatch between community respiration and the contribution of heterotrophic bacteria in the NE Atlantic open ocean: What causes high respiration in oligotrophic waters? J Mar Res 65: 545-560

Nagata T (2000) Production mechanisms of dissolved organic matter. In: Kirchman DL (ed) Microbial ecology of the oceans, 1st edn. Wiley-Liss, New York, NY, p 121-152

> Piazena H, Perez-Rodrigues E, Häder DP, López-Figueroa F (2002) Penetration of solar radiation into the water column of the central subtropical Atlantic Ocean - optical properties and possible biological consequences. Deep-Sea Res II 49:3513-3528

Polovina JF, Howell EA, Abecassis M (2008) Ocean`s least productive waters are expanding. Geophys Res Lett 35:L03618

Pomeroy LR, Sheldon JE, Sheldon WM Jr (1994) Changes in bacterial numbers and leucine assimilation during estimations of microbial respiratory rates in seawater by the precision Winkler method. Appl Environ Microbiol 60: 328-332

Pringault O, Tesson S, Rochelle-Newall E (2009) Respiration in the light and bacterio-phytoplankton coupling in a coastal environment. Microb Ecol 57:321-334

Quevedo M, Anadón R (2001) Protist control of phytoplankton growth in the subtropical north-east Atlantic. Mar Ecol Prog Ser 221:29-38

Riser SC, Johnson KS (2008) Net production of oxygen in the subtropical ocean. Nature 451:323-326

Robinson C, Williams PJ le B (2005) Respiration and its measurement in surface marine waters. In: del Giorgio PA, Williams PJ le B (eds) Respiration in aquatic ecosystems. Oxford University Press, New York, NY, p 147-160

Robinson C (2008) Heterotrophic bacterial respiration. In: Kirchman DL (ed) Microbial ecology of the oceans, 2nd edn, Wiley-Liss, Hoboken, NJ, p 299-334

Sampou P, Kemp WM (1994) Factors regulating plankton community respiration in Chesapeake Bay. Mar Ecol Prog Ser 110:249-258

Serret P, Robinson C, Fernández E, Teira E, Tilston G (2001) Latitudinal variation of the balance between plankton photosynthesis and respiration in the eastern Atlantic Ocean. Limnol Oceanogr 46:1642-1652

Sherr BF, del Giorgio PA, Sherr EB (1999) Estimating abundance and single-cell characteristics of respiring bacteria via the redox dye CTC. Aquat Microb Ecol 18:117-131

Shiah FK (1999) Diel cycles of heterotrophic bacterioplankton abundance and production in the ocean surface waters. Aquat Microb Ecol 17:239-246

Simon M (1994) Diel variability of bacterioplankton biomass production and cell multiplication in Lake Constance. Arch Hydrobiol 130:283-302

Sommaruga R, Sattler B, Oberleiter A, Wille A and others (1999) An in situ enclosure experiment to test the solar UVB impact on plankton in a high-latitude mountain lake. II. Effects on the microbial food web. J Plankton Res 21: 859-876

Teira E, Mouriño B, Marañón E, Pérez V and others (2006) Variability of chlorophyll and primary production in the Eastern North Atlantic Subtropical Gyre: potential factors affecting phytoplankton activity. Deep-Sea Res I 52: $569-588$

Torréton JP, Bouvy M, Arfi R (1994) Diel fluctuations of bacterial abundance and productivity in a shallow eutrophic tropical lagoon. Arch Hydrobiol 131:79-92

Tsai AY, Chiang KP, Chang J, Gong GC (2005) Seasonal diel variations of picoplankton and nanoplankton in a subtropical western Pacific coastal ecosystem. Limnol Oceanogr 50:1221-1231

Van Wambeke F, Tedetti M, Duhamel S, Sempéré R (2008) Diel variability of the heterotrophic bacterial production and UV doses in the South East Pacific. Biogeosciences Discuss 5:435-462

- Vaulot D, Marie D (1999) Diel variability of photosynthetic picoplankton in the equatorial Pacific. J Geophys Res 104:3297-3310

> Visser PM, Poos JJ, Scheper BB, Boelen P, van Duyl FC (2002) Diurnal variations in depth profiles of UV-induced DNA damage and inhibition of bacterioplankton production in tropical coastal waters. Mar Ecol Prog Ser 228:25-33

Zubkov MV, Sleigh MA, Tarran GA, Burkill PH, Leakey RJG (1998) Picoplanktonic community structure on an Atlantic transect from $50^{\circ} \mathrm{N}$ to $50^{\circ} \mathrm{S}$. Deep-Sea Res I 45 : 1339-1355 


\section{Appendix 1}

\section{a Lagragian-I}
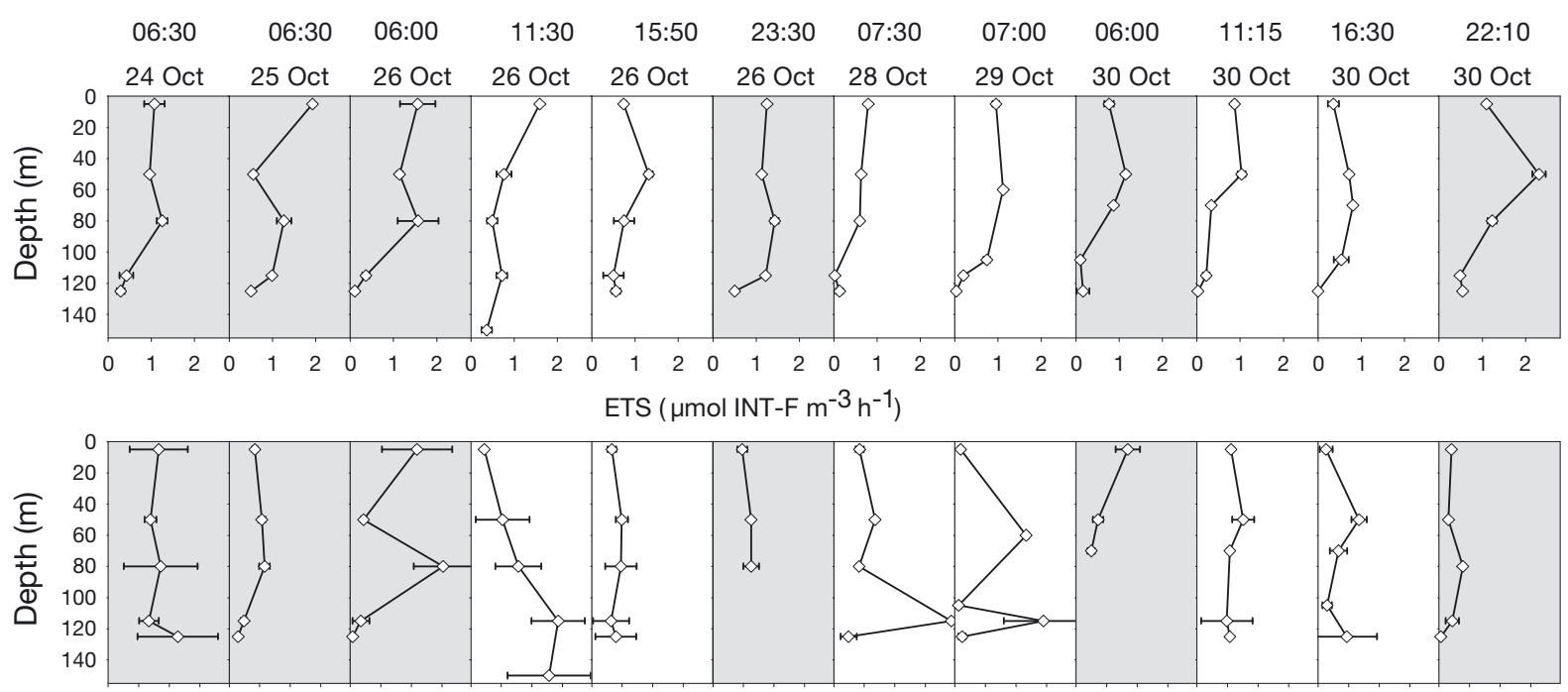

025507502550750255075025507502550750255075025507502550750255075025507502550750255075 $<0.8$ ETS (\%)

\section{b Lagragian-II}
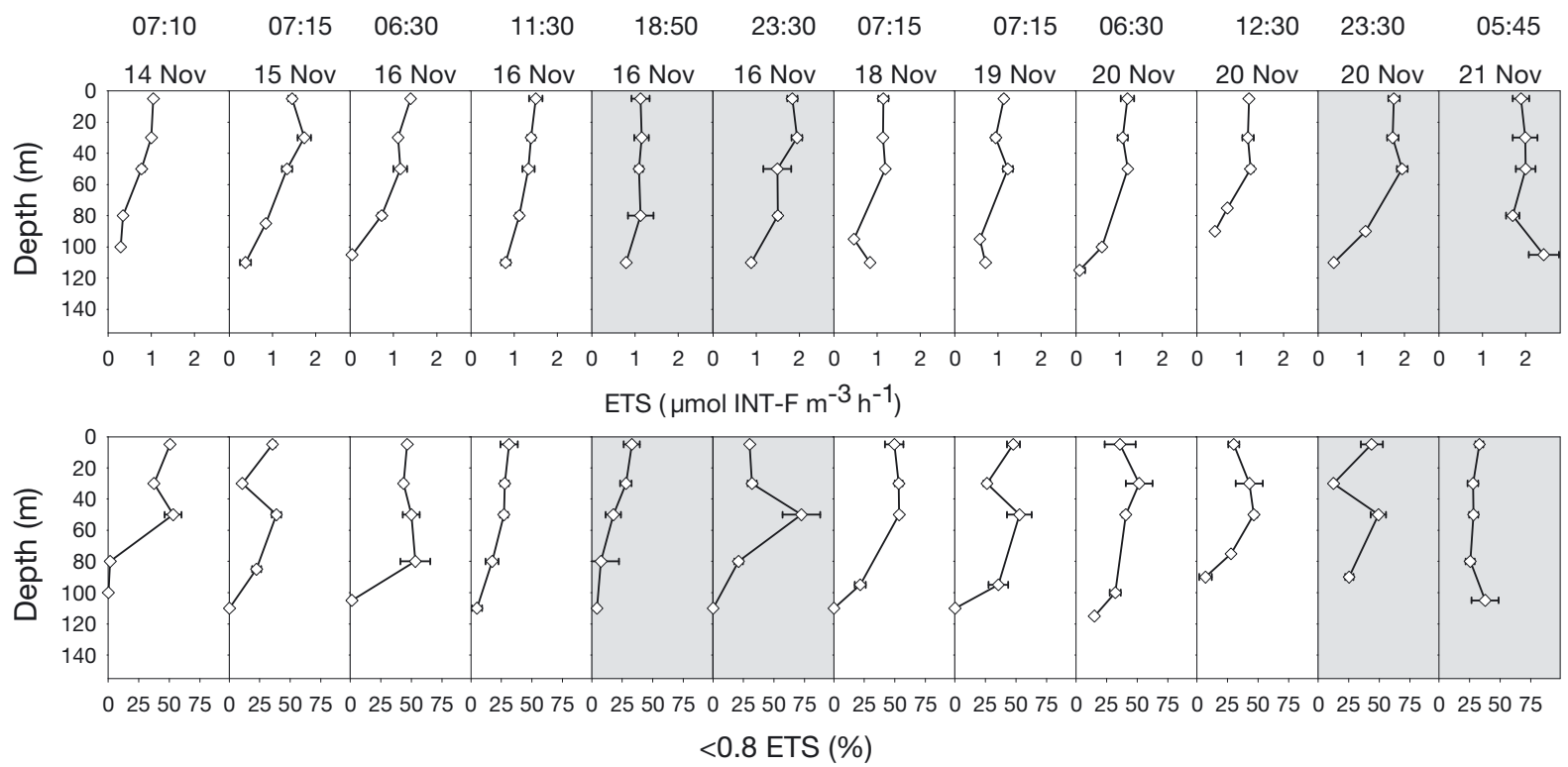

Fig. A1. Vertical profiles of total microbial plankton electron transport system (ETS) activity and the contribution of the $<0.8 \mu \mathrm{m}$ size-fraction to the total ETS activity during Lagrangian studies I (a) and II (b). Date and sampling time are indicated for each profile. Those profiles sampled during the night are indicated by a grey background. Error bars indicate standard errors

Editorial responsibility: Josep Gasol, Barcelona, Spain
Submitted: October 6, 2009; Accepted: June 24, 2010 Proofs received from author(s): August 23, 2010 